Златів, Леся. «Формування у магістрантів-філологів умінь аналізувати науково-навчальний мовознавчий текст». Лінгвостилістичні студї̈, вип. 10, 2019, с. 52-61.

Zlativ, Lesia. "Formation of the Skills to Analyze Scientific and Educational Linguistic Texts by the Master Degree Students in Philology". Linguostylistic Studies, iss. 10, 2019, pp. 52-61.

Удк 811.161.2'42

https://doi.org/10.29038/2413-0923-2019-10-52-61

\title{
ФОРМУВАННЯ У МАГІСТРАНТІВ-ФІЛОЛОГІВ УМІНЬ АНАЛІЗУВАТИ НАУКОВО-НАВЧАЛЬНИЙ МОВОЗНАВЧИЙ ТЕКСТ
}

\author{
Леся Златів \\ Рівненський державний гуманітарний університет, \\ Рівне, Україна
}

У статті проаналізовано різні підходи до визначення поняття «науковонавчальний текст» у науковій літературі, сформульовано дефініцію термінологічного сполучення «науково-навчальний мовознавчий текст» під кутом зору лінгводидактики вищої школи, обгрунтовано необхідність формування у магістрів-філологів умінь здійснювати аналіз науково-навчального мовознавчого тексту за структурносемантичними й комунікативно-прагматичними параметрами, розроблено схему аналізу, запропоновано систему текстових завдань аналітико-синтетичного типу для формування таких умінь у межах дисциплін лінгвістичного циклу В30.

Ключові слова: науково-навчальний текст, науково-навчальний мовознавчий текст, структурно-семантичні, комунікативно-прагматичні особливості тексту, аналіз тексту.

Zlativ Lesia. Formation of the Skills to Analyze Scientific and Educational Linguistic Texts by the Master Degree Students in Philology. The article substantiates the necessity of forming the masters-philologists' skills to analyze the scientific and educational linguistic text by structural-semantic and communicative-pragmatic parameters. For this purpose, the project of the Higher Education in Ukraine Standards, the university curricula and methodological materials for the philological faculties have been analyzed. As the study shows, the content of the academic disciplines does not provide the graduates with the opportunities and satisfactory basis for developing skills of the analysis of scientific and educational linguistic texts from the standpoint of their structural-semantic and communicative-pragmatic aspects. The scientific text relates to different genres of scientific and educational substyles, the author of which is usually a scientist-linguist, a teacher (a textbook, a guide, a course of lectures, lectures, a syllabus of discipline, methodical recommendations, a workshop, a collection of exercises, an electronic textbook, e-manual, etc.). The Master-philologist in the learning process should master the skills of how to analyze and produce such texts in the mentioned genres, since his further professional work as a teacher-linguist implies the creation of discipline syllabus, textbooks, manuals, methodological guides, lectures, development of practical and seminar schedules, system of exercises and tasks from a specific discipline, etc.In view of this, the article analyzes various approaches to the definition of the concept of "scientific and educational text" in the scientific literature. The author suggests the definition of the term-concept "scientific and educational linguistic text" in terms of the linguodidactics of higher education. The scientific-educational

(C) Златів Л., Східноєвропейський національний університет імені Лесі Українки, 2019.

Це стаття відкритого доступу на умовах CC BY-NC 4.0 
linguistic text is defined as a verbal component of the educational linguistic discourse, which has specific semantic-syntactic and communicative-pragmatic characteristics, intended for submitting scientific information and the establishment of a special communicative contact with the addressee in order to interest and encourage him to acquire new knowledge, necessary for the formation of the key professional competences in the disciplines of the linguistic cycle. The study of the scientific literature and the author's individual research of previous years provided a solid basis for designing the scheme of analysis of the scientific and educational linguistic text, which includes the general characterization of a text, analysis of the structural-semantic and communicative-pragmatic features. A system of the textual tasks of an analytical-synthetic type is proposed for the formation of such skills of the mastersphilologists with in the framework of the linguistic disciplines cycle of the HEI (higher educational institutions).

Key words: scientific and educational text, scientific and educational linguistic text, structural-semantic, communicative-pragmatic features of the text, analysis of the text.

Вступ. У проекті Стандарту вищої освіти України 3-поміж очікуваних результатів підготовки магістра філології виокремлюємо такі: «здійснювати науковий аналіз мовного й літературного матеріалу, інтерпретувати та структурувати його з урахуванням класичних і новітніх методологічних принципів, формулювати узагальнення на основі самостійно опрацьованих даних» (Стандарт 8). Щоб сформувати такі фахові компетентності у магістрів-філологів, необхідно систематично й послідовно практикувати різні види аналізу тексту на заняттях із дисциплін мовознавчого й літературознавчого циклу.

Аналіз освітніх програм, робочих програм, підручників та посібників із різних дисциплін філологічного циклу для студентів освітніх ступенів «бакалавр» та «магістр» зі спеціальності 035 Філологія (українська мова та література), а також багаторічний досвід викладання мовознавчих дисциплін на факультеті української філології Рівненського державного гуманітарного університету дозволяє констатувати таке: у змісті навчальних дисциплін закладено, а в підручниках та посібниках зреалізовано достатньо можливостей для формування у студентів умінь i навичок аналізу мовного матеріалу (фонетичного, морфологічного, словотвірного, морфемного, лексичного, синтаксичного, стилістичного, лінгвістичного та ін.), проте недостатньо - для аналізу науковонавчального мовознавчого тексту з погляду його структурно-семантичних та комунікативно-прагматичних особливостей. Саме це й зумовило вибір теми дослідження.

Сучасні мовознавці О. Баженова, Н. Ботвина, М. Гінзбург, І. Житар, В. Коваленко, С. Малихіна, Г. Онуфрієнко, С. Шепітько та ін. у своїх розвідках аналізували категорії та засоби наукового тексту, зокрема Н. Данилевська, М. Кожина, М. Котюрова, Н. Милованова, Т. Михайлюк, Г. Наєнко, Л. Славгородська, В. Шабуніна розглядали проблеми писемної та усної форм наукового мовлення, адресованості, діалогічності, експресивності, зв'язності, інтертекстуальності наукового тексту. А. Габідулліна, В. Карасик, А. Нікітіна, О. Томіліна, Ю. Щербініна проаналізували науково-навчальний 
текст у контексті навчально-педагогічного (освітнього, педагогічного) дискурсу, Т.Хомутова - в контексті сучасних лінгвістичних парадигм. О. Богатирьова досліджувала функціонально-стилістичні характеристики навчального мовленнєвого тексту. Н. Остражкова проаналізувала тлумачення змістового компонента педагогічного дискурсу лекції. В. Чернявська вивчала інтерпретацію навчального тексту. В. Чемпоєш здійснила комплексне дослідження семантико-синтаксичних та комунікативнопрагматичних особливостей навчального мовознавчого тексту.

У науковій літературі, присвяченій проблемам лінгводидактики вищої школи, досліджувана нами проблема частково висвітлена в працях А. Габідулліної, А. Нікітіної, Г. Онуфрієнко. Проте лінгводидактичні аспекти формування у магістрантів-філологів умінь аналізувати науковонавчальний мовознавчий текст за структурно-семантичними й комунікативно-прагматичними параметрами досі не вивчені.

Мета дослідження - проаналізувати різні підходи до визначення поняття «науково-навчальний текст» у науковій літературі, сформулювати дефініцію термінологічного сполучення «науково-навчальний мовознавчий текст» під кутом зору лінгводидактики вищої школи, обгрунтувати необхідність формування у магістрантів-філологів умінь здійснювати аналіз науково-навчального мовознавчого тексту за структурносемантичними й комунікативно-прагматичними параметрами, розробити схему аналізу, запропонувати систему текстових завдань аналітикосинтетичного типу для формування таких умінь у межах дисциплін лінгвістичного циклу В3О.

Матеріал і методи дослідження. Матеріалом для дослідження стали науково-навчальні мовознавчі тексти, дібрані з підручників та посібників для вищої школи з курсу сучасної української літературної мови та окремих його розділів (Плющ; Пономарів).

Відповідно до мети було використано такі методи дослідження: теоретичні: аналіз лінгвістичної, науково-методичної літератури з метою визначення поняття «науково-навчальний мовознавчий текст» під кутом зору лінгводидактики вищої школи, аналіз проекту Стандарту вищої освіти України та програмно-методичних матеріалів із метою виявлення можливостей для формування у магістрантів-філологів умінь здійснювати аналіз науково-навчального мовознавчого тексту за структурносемантичними й комунікативно-прагматичними параметрами; емпіричні: педагогічний експеримент для з'ясування рівня сформованості та можливості удосконалення у магістрантів-філологів таких умінь, а також перевірки ефективності запропонованої методики.

Результати дослідження та дискусія. Ключовими поняттями нашого дослідження $є$ науково-навчальний текст (далі - ННТ) та науковонавчальний мовознавчий текст (далі - ННМТ), тому проаналізуємо підходи до їхнього визначення в науковій літературі. 
А. Габідулліна розглядає ННТ як складник навчально-педагогічного дискурсу і виокремлює такі його диференційні ознаки, як тематичність, термінологічність, «вторинність, тобто адаптованість, спрощення тексту «науки» у процесі переходу до тексту навчання з метою його розуміння й залежно від адресата, відповідність логіці програми навчання, яка, у свою чергу, відповідає логіці дисципліни, яку викладають, послідовне розгортання контексту від відомого до невідомого (нового), від простого до складного, від часткового до загального, полікодовість ННТ, в якому, крім вербальних знаків (морфем, слів, речень), використовуються піктографічні зображення, шрифтове виділення, зміна кольору тощо» (13). 3-поміж класичних текстових категорій, описаних у лінгвістичній літературі (І. Гальперін, О. Москальська, О. Селіванова та ін.), А. Габідулліна найважливішими категоріями ННТ вважає інформативність, оцінність, інтертекстуальність, зв'язність і членованість.

Г. Онуфрієнко ННТ розглядає як «єдиний комунікативний блок, що має чітку, логізовану структурну організацію, яка формується під упливом двох основних факторів: характеру висвітлюваного змісту (тема - підтема комбінація підтем) та способу його презентації» (21). Комунікативними блоками $\epsilon$ його компоненти, розташовані в певній послідовності. Кожний із них може виконувати функції уточнення, роз'яснення, обгрунтування, доповнення, унаочнення і т. ін. Визначення цих функцій студентами сприяє адекватному розумінню тексту. ННТ обов'язково характеризується певною внутрішньою організацією, тобто має такі лексико-граматичні та структурні засоби, які роблять його доступним для розуміння, усвідомлення й запам'ятовування інформації та подальшого ії відтворення і використання (Онуфрієнко 21).

В. Шабуніна розглядає ННТ як внутрішньо діалогічний, який «не лише відтворює конкретну авторську позицію та зорієнтований на певного адресата, але й завжди є відповіддю на попередній контекст і передбачає зворотну реакцію» (17), а також аналізує засоби діалогічної організації НHТ технічної галузі в аспектах комунікативної лінгвістики, лінгвопрагматики та стилістики ресурсів, детально характеризує графостилістичні, лексико-семантичні, морфологічні та синтаксичні засоби підтримання комунікативного контакту між автором і адресатом, доводить, що при побудові ННТ застосовують «елементи моделі довідковоінформаційного текстотипу, які сприяють передаванню більшої кількості інформації без збільшення обсягу плану вираження, оптимізують комунікативний процес, відповідають сучасним стандартам більш інтенсивного інформаційного обміну» (6). На думку дослідниці, графостилістичні засоби ННТ охоплюють: виділення елементів НHТ за допомогою напівжирного шрифту, підкреслення, курсиву, рамки, величини літер; інтервал; субтекст іншої знакової системи; колір тексту; квадратні чи кутові дужки; примітки; поділ тексту на частини, розділи, підрозділи, пункти, підпункти, параграфи тощо. Синтаксичні засоби 
охоплюють: речення різної комунікативної спрямованості й синтаксичної структури; визначений автором порядок слів у реченні; однорідні та відокремлені члени речення; вставні й вставлені конструкції; явища синтаксичної анафори та катафори; абзацне членування тощо. Лексикосемантичні засоби ННТ вміщують: використання термінів, дефініцій; інтертекстуальні засоби, авторську суб'єктивну оцінку; покликання; наведення прикладів; привернення уваги адресата до результатів досліджень; інформування про хід викладу матеріалу; формулювання висновків тощо (Шабуніна 11-12).

Т. Хомутова визначає ННТ як предметно-знакову модель, що інтегрує чотири аспекти: когнітивний, мовний, соціальний і культурний, одиниці яких функціюють як єдине ціле за допомогою механізмів вербальної комунікативної діяльності в ситуаціях педагогічного дискурсу. Цілком поділяємо думку дослідниці, що «комунікативна діяльність як об'єктивація мовленнєвої діяльності об'єднує всі чотири аспекти в єдине ціле, вони взаємозумовлені, не існують один без одного і виокремлюються тільки з дослідницькою метою» (63).

В. Чемпоєш розглядає навчальний мовознавчий текст як вербальний компонент навчального мовознавчого дискурсу - «різновиду інституційного дискурсу, що є репрезентацією ситуації навчання в галузі філології, містить вербальний компонент, яким $€$ текст, та невербальні компоненти, що впливають на створення і сприймання тексту. Вербальний компонент виявляє себе як сукупність навчальних текстів, об'єднаних спільною мовознавчою темою» (44). Навчальний мовознавчий текстдискурс вона визначає як «сукупність семантико-синтаксичних та комунікативно-прагматичних характеристик мовлення у навчальній діяльності, зафіксованих письмово як взаємодія адресант - текст адресат» (169).

Наведені визначення поняття науково-навчального тексту дозволяють сформулювати власну його дефініцію 3 погляду лінгводидактики вищої школи. Отже, науково-навчальним мовознавчим текстом уважаємо вербальний компонент навчального мовознавчого дискурсу, що має специфічні семантико-синтаксичні та комунікативнопрагматичні характеристики, призначений для передавання наукової інформації та встановлення особливого комунікативного контакту 3 адресатом із метою зацікавити й заохотити його здобути нові знання, для формування фахових компетентностей із дисциплін мовознавчого циклу.

У питанні аналізу ННМТ необхідно розмежувати сфери семантики й прагматики. Ф. Бацевич стверджує, що «семантичні компоненти мовних явищ повідомляються, тобто мають стверджувальний характер; прагматичні ж - виражаються (як емоції, почуття, волевиявлення тощо), або мають характер пресупозиції, фонових знань» (27). Отже, прагматичні компоненти значення мовних одиниць залежні від ситуації спілкування і «не прораховуються, а впізнаються, переживаються» (28), тому не 
підлягають окремим раціональним операціям, зокрема запереченню. Ця властивість - один із основних чинників функціювання прагматично маркованих мовних засобів у тексті з її настановою впливу на реципієнта.

Аналіз НHМТ необхідно здійснювати, спираючись на найвагоміші диференційні його ознаки. Услід за В. Чемпоєш, яка здійснила грунтовне комплексне дослідження семантико-синтаксичних та комунікативнопрагматичних особливостей навчального мовознавчого тексту, з-поміж категорійних текстових ознак виокремлюємо такі диференційні ознаки HНMT: висока інформативність та інформаційна насиченість, інтерпретаційність, ілюстрованість мовними фактами, аргументованість, точність та однозначність змістової репрезентації, об’єктивність та узагальненість авторської позиції (Чемпоєш). Поділяємо думку дослідниці про те, що інформативність забезпечується передусім різними семантичними функціями вставлення із репрезентацією термінологічної варіантності та побіжного коментування, а також неспеціалізованими синтаксичними засобами - складними та простими ускладненими реченнями. Інтерпретація матеріалу реалізується в синонімічних рядах, синтаксичних структурах із семантикою власне-пояснення, конкретизації та включення. Функцію пояснення виконують вставлені компоненти речення, складнопідрядні та безсполучникові речення із різними типами пояснювальних відношень, а спеціалізованими засобами вираження семантичних варіантів інтерпретаційності $€$ переважно пояснювальноототожнювальні та пояснювально-виокремлювальні сполучники. Аргументованість у ННМТ реалізована складнопідрядними реченнями, підрядна частина яких репрезентує аргументацію і приєднується сполучниками та сполучними словами: що, оскільки, бо, адже, тому що, у зв'язку з тим що, через те що, завдяки тому що, внаслідок чого - та безсполучниковими реченнями, у яких друга й наступні предикативні частини містять аргументи. Для маркування та упорядкування аргументів, представлених у певній логічній послідовності, використовують слова отже,по-перше, по-друге, і нарешті, передусім, насамперед та ін.

Зв'язність та цілісність ННMT забезпечують спеціалізовані та неспеціалізовані лексико-синтаксичні засоби. Продуктивними в реалізації цих текстових ознак $є$ повтори, синоніми та вказівно-замінні займенники і прислівники; сполучники та сполучні слова, що пов'язують інформацію наступного речення з попереднім; вставні слова; неповні речення та речення узагальненого типу. 3-поміж прагматичних типів речень найпоширенішими в HНMT $\epsilon$ констативи, директиви та квеситиви. Суб'єктивна оцінка у НHМТ репрезентована значеннями ймовірності, гіпотетичності, переповідності, неповної впевненості, ствердження i виражена вставними словами переважно гіпотетичної семантики: мабуть, можливо, очевидно, ймовірно та вставними словосполученнями і реченнями зі значенням переповідності (Чемпоєш 169-171). 
ННМТ міститься в різних жанрах науково-навчального підстилю. Писемна його форма представлена жанрами, автором текстів у яких $\epsilon$ зазвичай учений-мовознавець, викладач (підручник, навчальний посібник, довідник, тексти лекцій, навчальна програма дисципліни, методичні рекомендації, практикум, збірник вправ, електронний підручник, електронний навчальний посібник тощо) або студент (конспект, доповідь, план, тези, реферативне повідомлення, анотація, відгук тощо). Усна форма монологічними (лекція, доповідь) та діалогічними (семінар, бесіда, консультація, дискусія, диспут) жанрами.

Магістрант-філолог у процесі навчальної діяльності має навчитись аналізувати й продукувати НHМТ у названих жанрах, оскільки подальша його професійна діяльність як викладача-мовника передбачає створення робочих навчальних програм, підручників, навчальних посібників, методичних посібників, лекцій, розроблення планів практичних i семінарських занять, системи вправ та завдань із конкретної дисципліни і т. ін.

На основі опрацьованої наукової літератури, а також власних досліджень (Златів) розроблено систему текстових вправ і завдань для формування у магістрантів умінь аналізувати НHMT за структурносемантичними й комунікативно-прагматичними параметрами. Поділимось досвідом її використання в межах навчальної дисципліни «Науковонавчальний мовознавчий текст», уведеної до блоку вибіркових дисциплін для магістрантів-філологів Рівненського державного гуманітарного університету (як відомо, мета цієї дисципліни - подати студентам відомості про теоретичні засади дослідження НHМТ у сучасній науці, показати значущість знання структурно-семантичних та комунікативнопрагматичних параметрів НHMT, а також прийомів його сприйняття (розуміння), відтворення й продукування для загальнотеоретичної i практичної підготовки філолога, сформувати навички різних видів аналізу HHMT).

Система включає низку аналітико-синтетичних і трансформаційних вправ та завдань, що мають частково-пошуковий або комплексний характер. Мета частково-пошукових завдань - актуалізувати здобувачами вищої освіти знання про НHМТ, його загальні характеристики, структурносемантичні та прагматичні особливості, навчити їх ідентифіковувати мовні засоби, що забезпечують інформативність та інформаційну насиченість, інтерпретаційність тексту, ілюстрованість мовними фактами, аргументованість, точність та однозначність змістової репрезентації, об’єктивність, узагальненість авторської позиції, визначати їх функції, замінювати синонімічними еквівалентами, трансформувати текст із певною комунікативною настановою.

Наведемо приклади таких завдань:

1. Прочитайте текст. Визначте його тему й основну думку. Поділіть на мінімальні частини змісту - мікротеми (або ССЦ). Усвідомте 
семантичну неоднорідність виділених мікротем. Згрупуйте мікротеми у більші смислові утворення - підтеми і теми. Встановіть ієрархію смислів у тексті, тобто розмістіть смислові одиниці кожного рівня в порядку підвищення їх семантичної ваги в тексті. Представте структуру тексту у вигляді рівневої схеми.

2. Оцініть ступінь інформативності тексту (ступінь змістової новизни для потенційного адресата). Визначте лексичні (лінгвістичні терміни, їх синонімічні еквіваленти) й синтаксичні (складні й ускладнені речення) мовні засоби, що забезпечують відповідний ступінь інформативності. Як потрібно змінити текст, щоб знизити (підвищити) ступінь його інформативності? Коли виникає така необхідність?

3. Знайдіть у тексті синтаксичні засоби, що забезпечують інтерпретаційність мовних фактів (пояснення поданої інформації, ілюстрованість прикладами). Поясніть їх функції. Замініть їх синонімічними еквівалентами.

4. Прочитайте текст. Визначте його тему, доберіть заголовок. Згорніть кожен абзац тексту до одного речення, а потім, об'єднавши ці речення, трансформуйте їх в одне просте речення, ускладнене однорідними членами та відокремленими прикладками. Порівняйте первинний $i$ вторинний тексти. Який різновид інформаційної компресії ви застосували? у яких мовленнєвих ситуаціях можна використовувати такий прийом скорочення тексту?

5. Знайдіть мовні засоби, за допомогою яких досягається зв'язність $i$ цілісність тексту (заголовки, підзаголовки, синоніми, часово-видова співвіднесеність дієслів, тема-рематична структура речень, вказівнозамінні слова, сполучники, сполучні слова й ін.). Визначте їхні функції.

6. Назвіть засоби, що забезпечують логічність викладу та послідовність презентації навчальної інформації в тексті (типи речень, порядок слів, композиція тексту, рубрикація тексту).

7. Які прагматичні типи речень (констативи, директиви, квеситиви) представлені в тексті? Наведіть приклади. Поясніть функції.

8. Чи є в тексті «метаавтор»? Визначте його роль. Знайдіть засоби вираження модальності (припущення, впевненості, невпевненості, переповідності, достовірності, реальності, сумніву, вагання, суб'єктивного погляду (суб'єктивної думки, оцінки), авторизованої гіпотетичності, неповної впевненості) в тексті.

Мета комплексних завдань - навчити здобувачів вищої освіти здійснювати комплексний аналіз науково-навчального мовознавчого тексту, взятого з будь-якого підручника чи посібника, з метою оцінки його якості та придатності для навчальних цілей. Такі вміння належать до ключових фахових компетентностей магістранта-філолога.

Наведемо приклад такого завдання:

Iз підручника «Вступ до мовознавства» виберіть текст. (Це може бути параграф чи частина параграфа, в якій вичерпно викладено якесь 
питання). Здійсніть комплексний аналіз тексту, скориставшись поданою схемою.

\section{Схема аналізу науково-навчального мовознавчого тексту}

I. Загальна характеристика тексту:

1. Заголовок тексту, його функції.

2. Тема, підтеми, мікротеми тексту.

3. Основна думка (ідея) тексту.

4. Тип мовлення.

5. Жанр мовлення.

II. Структурно-семантичні особливості тексту:

1. Ступінь і засоби інформативності тексту.

2. Засоби інтерпретаційності тексту.

3. Точність і однозначність викладу та засоби їх досягнення.

4. Засоби аргументації.

6. Об'єктивність та узагальненість позиції автора.

7. Засоби зв'язності, послідовність презентації інформації в тексті. III. Прагматичні особливості тексту:

1. Прагматичні типи речень і їх функції.

2. Засоби діалогічності.

\section{1. Наявність метаавтора.}

2.2. Засоби вираження модальності.

Аналіз ННМТ за структурно-семантичними й комунікативнопрагматичними параметрами можна застосовувати й у межах інших дисциплін мовознавчого циклу, що читаються для магістрантів-філологів (наприклад, «Методологія філологічних досліджень», «Методика викладання філологічних дисциплін у вищій школі», «Комунікативна лінгвістика», «Теорія та практика мовної комунікації, «Прагмалінгвістика» та ін.).

Висновки та перспективи дослідженнь. Отже, у цій статті ми сформулювали визначення поняття «науково-навчальний мовознавчий текст» під кутом зору лінгводидактики вищої школи, обгрунтували необхідність формування у магістрантів-філологів умінь аналізувати науково-навчальний мовознавчий текст за структурно-семантичними й комунікативно-прагматичними параметрами, проаналізувавши проект Стандарту вищої освіти України та програмно-методичні матеріали (навчальні програми, підручники, посібники з мовознавчих дисциплін), розробили схему аналізу ННMТ, запропонували систему текстових завдань для формування таких умінь у межах дисциплін лінгвістичного циклу В30.

Перспективи вбачаємо у вивченні методичних аспектів формування у магістрантів-філологів умінь здійснювати інші види аналізу НHМТ (наприклад, дискурсний, когнітивний, лінгводидактичний). 


\section{Список використаної літератури}

Бацевич, Флорій. Основи комунікативної лінгвістики. Київ: ВЦ «Академія», 2009.

Габідулліна, Алла. Навчально-педагогічний дискурс: категоріальна структура та жанрова своєрідність (на прикладі шкільного предмета "російська мова»). Автореф. дис. ... д-ра філол. наук: 10.02.02. Київ, 2010.

Златів, Леся. «Робота з науково-навчальним текстом під час засвоєння студентамифілологами дисципліни «Текстознавство»». Науковий вісник Волинського національного університету імені Лесі Українки. Серія: Філологічні науки, № 2, ч. 1, 2011. с. 103-9.

Онуфрієнко, Галина. Науковий стиль української мови: навчальний посібник 3 алгоритмічними приписами. 2-ге вид. Київ: Центр учбової літератури, 2009.

Плющ, Марія. Граматика української мови. У 2 ч. Київ: Вища школа, 2005.

Пономарів, Олександр. Стилістика сучасної української мови. Київ: Либідь, 1992.

Стандарт вищої освіти магістра філології (проект). URL: https://mon.gov.ua/ storage/app/.../035-filologiya-magistr22.05.2017.docx .

Хомутова, Тамара. «Научный текст: единицы интегральной модели». Вестник ЮжноУральского государственного университета. Серия: Лингвистика, вып. 10, № 1 (177), 2010, с. 60-6.

Чемпоєш, Валентина. Навчальний мовознавчий текст: семантико-синтаксичний та прагматичний аспекти. Дис. ... канд. філол. наук: 10.02.01. Київ, 2017.

Шабуніна, Вікторія. Засоби діалогічної організації науково-навчальних текстів технічної галузі в сучасній українській мові. Автореф. дис. ... канд. філол. наук: 10.02.01. Дніпропетровськ, 2010.

\section{References}

Batsevych, Florii. Osnovy komunikatyvnoi linhvistyky. Kyiv: VTs "Akademiia”, 2009.

Gabidulina Alla. Educational discourse: categorical structure and genre specifity (on the basis of the school subject "Russian"). Doctoral Thesis. Kyiv, 2010.

Zlativ, Lesia. "Robota $\mathrm{z}$ naukovo-navchalnym tekstom pid chas zasvoiennia studentamyfilolohamy dystsypliny "Tekstoznavstvo"'”. Naukovyi visnyk Volynskoho natsionalnoho universytetu imeni Lesi Ukrainky. Seriia: Filolohichni nauky, no 2, part 1, 2011, pp. 103-9.

Onufriienko, Halyna. Naukovyi styl ukrainskoi movy: navchalnyi posibnyk z algorytmichnymy prypysamy. $2^{\text {nd }}$ ed. Kyiv: Tsentr uchbovoi literatury, 2009.

Standart vyshchoi osvity mahistra filolohii (proekt). mon.gov.ua/ storage/app/.../035filologiya-magistr22.05.2017.docx

Pliushch, Mariia. Hramatyka ukrainskoi movy. 2 vols. Kyiv: Vyshcha shkola, 2005.

Ponomariv, Oleksandr. Stylistyka suchasnoi ukrainskoi movy. Kyiv: Lybid, 1992.

Homutova, Tamara. "Nauchnyj tekst: edinicy integral'noj modeli". Vestnik Juzhno-Ural'skogo gosudarstvennogo universiteta. Serija: Lingvistika, iss. 10, no 1 (177), 2010, pp. 60-6.

Chempoiesh, Valentyna. Educational Linguistic Discourse: Semantic-Syntactic and Pragmatic Aspects. PhD dissertation. Kyiv, 2017.

Shabunina, Viktoriia. Means of dialogical organizing of scientific-educational texts of technical sphere in the modern Ukrainian language. PhD Thesis Abstract. Dnipropetrovsk, 2010. 